\title{
Towards a Model of Engaging Online Students: Lessons from MOOCs and Four Policy Documents
}

\author{
Khe Foon Hew
}

\begin{abstract}
The paper describes a model of engaging students in fully online or blended learning environments. To do this, I first discuss the notion of student engagement and how it relates to the Self-Determination Theory of motivation. Next, I reviewed a number of online learning policy guidelines from four professional councils around the world in order to elicit specific guidelines related to the design of online learning courses, and student engagement. Following that, I analyzed two most highly-rated MOOCs. I analyzed the structural features of the two MOOCs and the comments of both participants who completed the courses, and who partially completed or dropped out. Altogether, comments from 839 participants were examined. Finally, using these empirical data and the policy guidelines from the four professional organizations, I outline a rudimentary model of engaging students in online learning courses, based on six major instructional design elements.
\end{abstract}

Index Terms-Online learning, blended learning, massive open online learning, MOOCs, e-learning, instructional design, engagement, motivation, self-determination theory.

\section{INTRODUCTION}

Online learning for both students and teachers has become one of the fastest growing trends in educational uses of technology [1]. Essentially, the main purpose of online learning is to offer learners access to education at their own pace and time, as well as lowering the average overall per-learner cost. The recent developments of online educational resources particularly Massive Open Online Courses (MOOCs) have further fueled public attention and interest in online learning.

A MOOC is an online course which allows virtually anyone with an Internet connection to attend for free. Currently, many universities around the world have offered MOOCs, usually in partnerships with providers or companies such as Coursera, and edX. According to McMinn [2], MOOCs are being embraced by every college and university atop the U.S. News and World Report's national university rankings. Over in Asia, the National University of Singapore and the Nanynag Technological University have decided to offer MOOCs with Coursera, while the University of Hong Kong has announced its plans to offer MOOCs with edX.

Clearly, there is now much interest in online learning given the growing popularity of MOOCs. However, engaging students in MOOCs or online learning is not easy. Not all MOOCs are well received by students who enrolled in them.

Manuscript received April 13, 2014; revised June 15, 2014.

Khe Foon Hew is with the Division of Information \& Technology Studies, Faulty of Education at the University of Hong Kong, Pokfulam Road, Hong Kong (e-mail: kfhew@hku.hk).
So what makes a MOOC engaging? How can an online course be designed in a way that engages students to complete it?

These questions are not new. But there will be two new aspects in my treatment of them. First, I will be primarily concerned with a new kind of instructional environment one involving large fully online courses. I exclude purely print-based correspondence education, and stand-alone educational software programs that do not have an Internet-based instructional component. Second, as a source of insight into the problem, I analyze a number of online learning policy guidelines from four professional councils, and two highly rated MOOCs. In other words, I try to answer the following two questions: a) what are the main recommendations offered by professional councils for designing an online course? and b) what specific instructional design factors related to highly rated MOOC may have engaged students to complete an online course? With this background, a rudimentary model of engaging students in online learning courses can be developed based on six instructional design elements: course information, course resources, interaction, active learning, frequent monitoring of learning, and making meaningful connections. This model can provide guidance to future designers of online learning environments.

\section{Student ENGAGEMENT}

\section{A. Engagement}

Student engagement can be defined as the extent or degree of a student's involvement in a learning activity [3]. Numerous number of models been proposed to describe the various aspects of engagement. Nevertheless, despite the fact that different models accentuate different aspects of engagement, there are substantial overlaps and similarities among them [4], [5]. In a major literature review, Fredricks $e t$ al. [5] identified three main aspects of engagement - a) behavioral engagement which refers to students participating in a learning activity such as completing an assignment, attending classes, or contributing in discussions, b) affective engagement which refers to students' emotional responses or feeling (positive or negative) toward teachers, peers, learning, and school, and c) cognitive engagement which refers to "the deliberate task-specific thinking that a student undertakes while participating in an activity" [6]. Instances of cognitive engagement may include asking and answering questions, giving explanations, justifying an argument, and contributing ideas [6]. It may be useful to adopt the following three questions to help one differentiate the three aspects of student engagement: behavior (what are students doing?), affect 
(what are students feeling?), and cognitive (what are students thinking?) [6].

\section{B. Engagement and Motivation}

Reeve [3] defines motivation as "any force that energizes and directs behavior". I view engagement as the observable display or manifestation of motivation; a view consistent with that held by other scholars [3], [7]. Motivation drives and influences engagement.

One of the most commonly used theories to explain motivation is the self-determination theory (SDT) which assumes that all individuals regardless of gender, age, or culture possess three fundamental psychological needs that move them to act or not to act - the needs for autonomy, relatedness, and competence [8], [9].

Autonomy refers to the need for freedom or perceived choice over one's action [8], [9]. Previous studies have found that students with a greater sense of autonomy show greater levels of engagement [10], [11]. Relatedness refers to the need for an individual to connect or interact with other people [12], while competence refers to the need for a person to master one's pursuits or learning [13]. Fig. 1 depicts graphically how the three psychological needs posited by SDT may influence the three aspects of engagement.

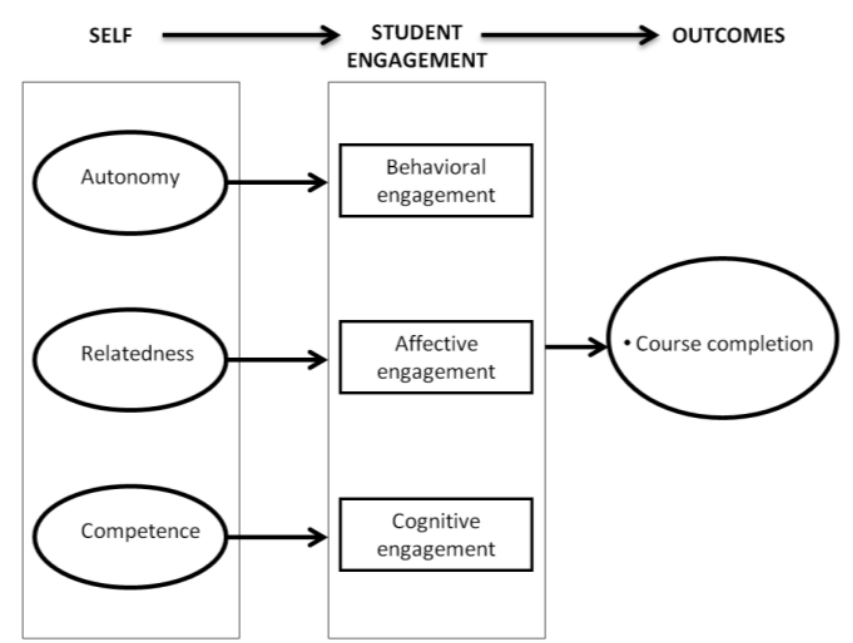

Fig. 1. A model of student engagement organized around SDT.

\section{POLICY GUIDELINES FROM Four PROFESSIONAL COUNCILS}

Policy documents from four different professional councils were consulted. In selecting these professional online learning councils, I have purposefully chosen councils from various parts of the world. Table I presents an overview of the various policy guidelines, specifying their main focus, the professional councils supporting them, and the countries involved in the initiative.

Benchmarks for Technology Supported Teaching and Learning, developed by the Australasian Council on open, distance and e-learning [14]. The main purpose of ACODE is to improve policy in open and e-learning in the Australasian higher education sector. The Benchmarks for Technology Supported Teaching and Learning policy document describes several benchmarks to plan for the integration of technology in open and e-learning environments, along with their respective performance indicators.
Interregional Guidelines for the Evaluation of Distance Education Programs (Online Learning), developed by the Council of Regional Accrediting Commissions [15] to help institutions plan and assess the quality of their online learning courses. This document describes nine hallmarks of quality for distance learning including online learning. Examples of the types of evidence an institution might use to evaluate whether it meets each quality hallmark are also provided.

TABLE I: OVERVIEW

\begin{tabular}{|c|c|c|c|}
\hline Council & Main focus & Sponsors & Country \\
\hline $\begin{array}{l}\text { Benchmarks for } \\
\text { Technology } \\
\text { Supported Teaching } \\
\text { and Learning }\end{array}$ & $\begin{array}{l}\text { To guide policy } \\
\text { in implementing } \\
\text { open, distance } \\
\text { and e-learning }\end{array}$ & $\begin{array}{l}\text { Australasian } \\
\text { Council on } \\
\text { open, distance } \\
\text { and e-learning }\end{array}$ & Australia \\
\hline $\begin{array}{l}\text { Interregional } \\
\text { Guidelines for the } \\
\text { Evaluation of } \\
\text { Distance Education } \\
\text { Programs (Online } \\
\text { Learning) }\end{array}$ & $\begin{array}{l}\text { To help institutes } \\
\text { plan \& assess } \\
\text { online learning } \\
\text { courses }\end{array}$ & $\begin{array}{l}\text { Middle States } \\
\text { Commission } \\
\text { on Higher } \\
\text { Education }\end{array}$ & USA \\
\hline $\begin{array}{l}\text { Open and Distance } \\
\text { Learning Quality } \\
\text { Council Standards }\end{array}$ & $\begin{array}{l}\text { To improve } \\
\text { quality in all open } \\
\text { or distance } \\
\text { learning }\end{array}$ & $\begin{array}{l}\text { Open \& } \\
\text { Distance } \\
\text { Learning } \\
\text { Quality } \\
\text { Council }\end{array}$ & UK \\
\hline $\begin{array}{l}\text { Guidelines for the } \\
\text { Implementation of } \\
\text { Effective E-learning } \\
\text { Courses based on } \\
\text { Collaboration }\end{array}$ & $\begin{array}{l}\text { To improve the } \\
\text { design \& } \\
\text { implementation } \\
\text { of online } \\
\text { collaboration }\end{array}$ & $\begin{array}{l}\text { European } \\
\text { Commission }\end{array}$ & $\begin{array}{l}\text { Italy, } \\
\text { France, } \\
\text { Germany, } \\
\text { Finland }\end{array}$ \\
\hline
\end{tabular}

Open and Distance Learning Quality Council Standards, developed the Open \& Distance Learning Quality Council in the UK [16]. The objective of ODLQC is to identify and improve quality of teaching and learning in all open or distance education setting, including blended learning and e-learning courses. Specifically, the Open and Distance Learning Quality Council Standards document spells out several standards or guidelines with respect to areas such as the intended learning outcomes, use of course resources, learner support, the proper way for open learning vendors to sell their products, and the requirement for vendors to provide appropriate tutors.

Guidelines for the Implementation of Effective E-learning Courses based on Collaboration, funded with support from the European Commission [17]. The document provides practical help for educators to execute effective e-learning courses based on collaboration with an emphasis on the design and implementation aspects. The document was a result of work carried out by a number of universities including the University of Bologna (Italy), Ludwig-Maximilians-Universitat (Germany), the University of Turku (Finland), CEMIC-GRESIC (France), and the University of Neuchâtel (Switzerland).

Comparative analysis of the four policy documents revealed a large number of guidelines related to many various themes. In this paper, however, I will focus on only themes specifically related to the design of online learning courses, as well as student engagement. These themes can be loosely organized under five major categories: a) course expectation/information, b) student-student contact, c) student-faculty contact, d) instructional strategy, and e) 
course resources/materials. Table II summarizes these categories along with some representative examples of guidelines suggested by the policy documents.

TABLE II: INSTRUCTIONAL DESIGN - CATEGORIES AND REPRESENTATIVE GUIDELINES FROM FOUR ONLINE LEARNING POLICY DOCUMENTS

\begin{tabular}{|c|c|c|}
\hline Category & Representative guideline & $\begin{array}{l}\text { Primary aspect of } \\
\text { engagement } \\
\text { likely to be } \\
\text { involved }\end{array}$ \\
\hline $\begin{array}{l}\text { Course } \\
\text { expectation/ } \\
\text { information }\end{array}$ & $\begin{array}{l}\text { Each course includes a clear } \\
\text { statement of what the learner } \\
\text { can hope to achieve on } \\
\text { successful completion. Each } \\
\text { course starts from a clearly } \\
\text { stated level of ability }{ }^{(\mathrm{c})} \\
\text { - The curriculum is coherent in its } \\
\text { content and sequencing of } \\
\text { courses and is effectively } \\
\text { defined in easily available } \\
\text { documents including course } \\
\text { syllabi and program } \\
\text { descriptions } \\
\text { (b) }\end{array}$ & - Behavioral \\
\hline $\begin{array}{l}\text { Student-student } \\
\text { contact }\end{array}$ & $\begin{array}{l}\text { - Course design and delivery } \\
\text { supports student-student } \\
\text { interaction }{ }^{(\mathrm{b})} \\
\text { - Use a learning environment that } \\
\text { is easy to handle for everyone }{ }^{(\mathrm{d})} \\
\text { - Use different kinds of } \\
\text { collaboration tools like email, } \\
\text { forum, chat }^{(\mathrm{d})}\end{array}$ & - Affective \\
\hline $\begin{array}{l}\text { Student-faculty } \\
\text { contact }\end{array}$ & $\begin{array}{l}\text { - Course design and delivery } \\
\text { supports faculty-student } \\
\text { interaction }{ }^{(\mathrm{b})} \\
\text { - Imposing the use of forum } \\
\text { instead of sending email to the } \\
\text { tutor }^{(\mathrm{d})}\end{array}$ & - Affective \\
\hline $\begin{array}{l}\text { Instructional } \\
\text { strategy }\end{array}$ & $\begin{array}{l}\text { - Progress is monitored, and } \\
\text { learners are provided with } \\
\text { prompt and helpful comments } \\
\text { on their progress in relation to } \\
\text { learning expectations and } \\
\text { goals } \\
\text { - Each course facilitates learner } \\
\text { progress to a greater level of } \\
\text { ability } \\
\text { - Pedagogical application is } \\
\text { comprehensively based on both } \\
\text { sound educational research and } \\
\text { good practice }\end{array}$ & - Cognitive \\
\hline $\begin{array}{l}\text { Course } \\
\text { resources/ } \\
\text { materials }\end{array}$ & $\begin{array}{l}\text { - Course materials do not contain } \\
\text { significant errors of fact, } \\
\text { misleading or out-of-date } \\
\text { information, concepts or } \\
\text { approaches. Course materials } \\
\text { are structured to facilitate } \\
\text { individual study }{ }^{(\mathrm{c})}\end{array}$ & - Cognitive \\
\hline
\end{tabular}

(a) Benchmarks for Technology Supported Teaching and Learning (b) Interregional Guidelines for the Evaluation of Distance Education Programs (Online Learning)

(c) Open and Distance Learning Quality Council Standards

(d) Guidelines for the Implementation of Effective E-learning Courses based on Collaboration

\section{LimitATIONS OF THE POLICY GUIDELINES}

I have just described a list of guidelines from four professional councils to improve the quality of teaching and learning in online learning environments. However, some of the suggested guidelines are unfortunately too general. They are not specific enough to inform instructors what they should exactly do before the or during the running of an online course. For example, the guideline "Pedagogical application is comprehensively based on both sound educational research and good practice" is too vague to provide any practical help to the online educator. It does not clarify or give examples of any sound educational research or practice. Another example is the guideline, "Each course facilitates learner progress to a greater level of ability". But, how do we actually facilitate learner progress? No concrete suggestion or advice is given in the particular policy document.

Therefore, one of the main purposes for my analyzing the two most highly-rated MOOCs (described in the next section) is to give more concrete guidelines for educators to use, and to uncover additional design categories and guidelines if available.

\section{A Study of Two Most Highly-Rated Moocs}

\section{A. Overview of the MOOCs}

This present study is based on the analysis of participants' comments collected on March 8, 2014 using an open public MOOC review and rating website coursetalk (http://coursetalk.org/), as well as the course structural aspects of two most highly-rated MOOCs. Course structural features included elements such as whether certification is awarded, the type of assessment utilized, the types of course resources used, and so on.

At the time of writing, coursetalk lists and ranks a total of 16,383 MOOCs from a wide variety of providers such as Coursera, edX, Udacity, and Canvas Network. Of these 16,383 MOOCs, 6,424 were free of charge for anyone to sign up, while 9,969 required a participant to pay money to enroll in the course. An example of the latter is the "Google Adwords Course: Invest \& profit with live training" MOOC from Udemy which charges participants US\$995 to sign up.

In this study, I selected two most highly-rated MOOCs out of the entire corpus of 16,383 courses. These two MOOCs were: "An Introduction to Interactive Programming in Python", and "Epidemics - the Dynamics of Infectious Diseases". The former (hereby referred to as the Python MOOC) was offered by Rice University in partnership with Coursera, while the latter (hereby referred to as the Epidemics MOOC) was offered by The Pennsylvania State University, also in partnership with Coursera.

The Python MOOC had a total average of 4.9 out of a 5 -star rating scale in terms of course quality, and garnered 595 reviews at the time this paper is being written. This MOOC, taught by four instructors, introduced the basics of programming in Python. The main focus was on building simple interactive games such as Pong, Blackjack and Asteroids.

The Epidemic MOOC, on the other hand, had a total average of 4.8 stars in terms of course quality, and garnered 315 reviews. The course covered a range of topics including the history of infectious diseases, basic concepts of disease dynamics, spread of diseases, control of diseases, and the 
future of infectious diseases such as digital epidemiology. A total of eight instructors were involved in teaching the course. Some of the typical participants' comments regarding the Epidemic MOOC include: "I had no previous experience, and this course was the best of the four I've taken so far", "I think that this course is the most interesting from the other courses", and "Absolutely brilliant! Best MOOC I have ever taken. It is not only about the subjects addressed, but also how they are presented, and this course manages both extremely well."

The instructors of both the Python and Epidemics MOOCs structured their courses very similar to traditional higher education courses. The instructors had a syllabus, along with a course content that typically consisted of readings, discussions via online forums, assignments which consisted of quizzes, and/or mini-projects, and videos of lectures that are pre-recorded by the instructors prior to the lessons. More specifically, the Python MOOC had weekly mini-project that were associated with the particular topic taught in that week, as well as two quizzes each week to reinforce learning. Moreover, the course also required students to do peer assessment each week on their course mates' mini-projects. Students were provided with a grading rubric which laid out the criteria to evaluate the mini-projects. The Epidemics MOOC, on the other hand, had only weekly 10-question quizzes.

Students could start each week's lesson by watching the video lectures, read the assigned material such as textbook and articles, participate in online discussions with other learners, and complete the quizzes and/or mini-projects. Students could view and pause the video lectures at their own pace to take notes. The video lectures of both courses were conducted in English. However, all video lectures in both MOOCs had accompanying subtitles which helped students to follow what the instructors said.

To promote honesty and minimize cheating, students participating in both courses must agree to an honor code set by Coursera which includes: a) I will register for only one account, b) My answers to homework, quizzes and exams will be my own work except for assignments that explicitly permit collaboration, c) I will not make solutions written by me or official solutions provided by the course instructors available to anyone else, and d) I will not engage in any other activities that will dishonestly improve my results or dishonestly improve or hurt the results of others.

Finally, students who completed both MOOCs would receive a Statement of Accomplishment signed by the professors teaching the course. The statements of accomplishment were provided free of charge

\section{B. Data Collection and Analysis of Participants' Comments}

In this section, I analyzed the comments of participants who completed the two courses, as well as those who partially completed or dropped out. Comments from participants who are currently taking the MOOCs were excluded. To help participants in giving their comments, coursetalk provides some guiding questions including: a) What was your prior experience with the subject? b) How does this course compare with others? c) What did you like/dislike about the course?
Altogether, comments from a total of 910 participants were analyzed. Of these 910 participants, 810 completed at least one of the two most highly-rated MOOCs, and 29 partially completed or dropped out. Comments from 71 participants who reported that they were still taking the course were excluded. Each participant's comment was analyzed using the constant-comparative method to identify themes that were related to instructional design factors that could have contributed to students' success or failure in completing the courses. Participants' comments pertaining to specific ways to improve the courses were also analyzed as such inputs could suggest useful guidelines to enhance the design of future online learning courses.

\section{FINDINGS FROM THE PARTICIPANTS' COMMENTS}

Findings from the participants' comments can be categorized into five major themes: a) fostering active learning strategies, b) monitoring of learning, c) making meaningful connection, d) promoting interaction, and e) using helpful course resources. Each of these themes will be described in the following sections.

\section{A. Fostering Active Learning}

Active learning may be defined as instructional activities that involve students in doing things and thinking about the things they are doing [18]. The instructors of the Python MOOC essentially utilized active learning by requiring students to complete weekly mini-projects that counted towards their final marks. These mini projects required students to build actual games using the concepts taught in the particular week or previous weeks. Students found this strategy motivating and a useful way to learn the programming language:

"The fun mini-projects give us incentive to make things work so we can actually play the results of our efforts." (Student A, Python MOOC).

"It was an awesome experience which combined building games and at same time learning a new language." (Student $\mathrm{C}$, Python MOOC).

The instructors of the Epidemics MOOC employed two online games - Vax! and MOOCdemic so that students could apply some of the principles taught in the lessons by simulating the spread of infections.

"In comparison to other courses this one was great and even had a game to show how epidemics work." (Student M, Epidemics MOOC).

"I enjoyed 'scanning for infected' on the Moocdemic game and learning how to prevent epidemics on the VAX! game." (Student K, Epidemics MOOC).

\section{B. Monitoring Learning}

Both MOOCs employed the use of weekly auto-graded quizzes to monitor student learning and provide feedback on students' performance on the questions. These quizzes were created to test the specific concepts taught in a particular week. Some representative students' comments about the use of quizzes are as follows: 
"The quizzes are relevant to the mini projects as they re-enforce what you learn for a given week." (Student R, Python MOOC).

"The quizzes made you think and helped recollect the week's main subjects." (Student B, Epidemics MOOC).

In addition to the weekly quizzes, the instructors of Python MOOC employed weekly optional practice exercises. Each exercise contained a problem that students needed to solve such as to write a Python statement that calculates and prints the number of seconds in 8 hours, 15 minutes and 20 seconds. Each problem contained two links - one for a template that students could use as a starting point, and the other the instructors' solution to the problem.

\section{Making Meaningful Connection}

To continue engaging students beyond the initial excitement of signing up for a course, one would typically require the use of a certain "hook" to sustain their interest. One strategy to do this is by connecting students to actual practices in the larger world which they could identify. Instructors of the Python MOOC, for example, connected the programming concepts taught to actual popular games such as Pong, Blackjack, Asteroids which students could easily identify. Instructors of the Epidemics MOOC, on the other hand, connected the concepts of infectious diseases with well-chosen real world case studies.

"Real world examples given in the lectures helped in understanding the theory in a better way." (Student W, Epidemics MOOC).

\section{Promoting Interactions}

Interactions, particularly between the instructors and students, are probably the most critical factor in determining the degree of student engagement in an online course. A low degree of student-faculty contact would cause students to feel they are abandoned in the course, hence why continue in it when no one seems to care?

To promote student-faculty interaction, the instructors of Python MOOC created a dedicated course email (Code Clinic) for students to seek instructor help. Students could email a link of their work to the Code Clinic and one of the staff would look at the students' code and help debug the specific problem.

"A great resource was their Code Clinic where you could send in your program and they will help you debug. The response time was typically within 2 hours of sending an email." (Student N, Python MOOC).

"The professor answered no less than 2000 e-mails directly sent by students to the course's Code Clinic." (Student H, Python MOOC).

Fig. 2 shows a typical weekly cycle of help requests for the Code Clinic during the Spring 2013 session of the Python MOOC [19]. Each help request (and possible follow-up questions) generated on average 1.79 replies from the course staff. The average response time for a help request was about 42 minutes.

The instructors of Epidemics MOOC employed an "ask-us-anything" feature where they would answer specific questions from student discussion forums in video format.

"Constant interaction with the organizers was very motivating, as they answered questions students posed throughout the course, and seeing them in the videos discussing and responding to these made all the difference." (Student L, Epidemics MOOC).

Besides the need for instructor interaction, students also desire to interact with their peers as this could build a sense of community in the online learning environment:

"The unsung hero is the Discussion Forum. It provided useful information from the professors and students and fostered a sense of class community. It also allowed more advanced students to mentor beginners, providing an engaging experience across skill levels." (Student B, Python MOOC).

"The discussion forums provide a great chance to swap ideas and knowledge." (Student J, Epidemics MOOC).

Most of the student-student interactions took place in the text-based forums. To foster student participation, it is important to enforce certain ground rules such as be respectful in voicing viewpoints [20].

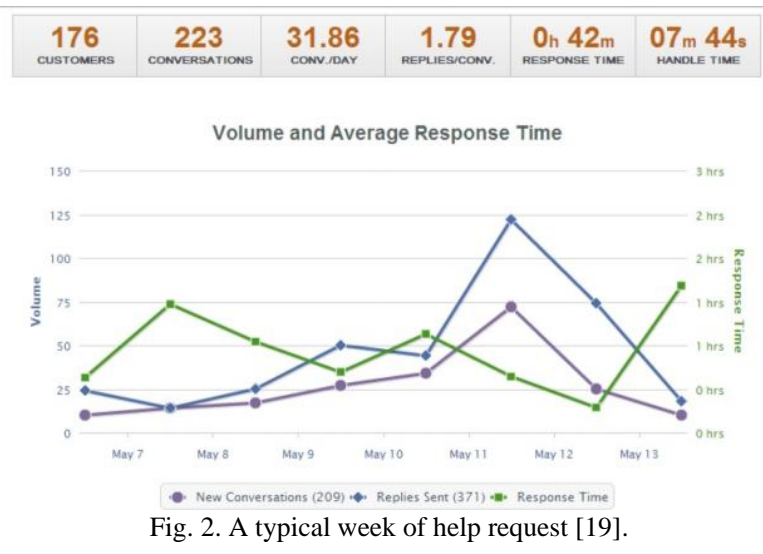

\section{E. Using Helpful Course Resources}

The use of course resources also plays a major role in fostering student engagement in online courses. This is due to the fact that students spend most of their time interacting with course resources. Therefore, if the resources are not helpful, students would not stay engaged for long and may eventually drop out.

Analysis of the two MOOCs showed that the main course resource for teaching each week's topic was the online video lecture. The use of videos, which presented the image and voice of the instructors, served as a useful tool to project an instructor's social presence into the MOOC learning environment. But, how exactly did the instructors of both MOOCs try to engage students through the videos?

Analysis of the participants' comments revealed several strategies utilized, as well as several recommendations that would keep students engaged and learn from the videos. Collectively, these nine strategies included the following: a) Use of 'bite-size' videos (mostly about 5-6 minutes long for Epidemics MOOC, and between 5-17 minutes for Python MOOC) with relevant pictures and animations to illustrate concepts, b) Present information in simple-to-understand 
language, c) Use a multiple lecturer model to add various perspectives to the course and keep students interested, d) Give relevant, interesting, accurate, and up-to-date information, e) Use captions on video to help student follow the presentation of materials, f) Downloadable video lectures to avoid potential online stall or crash, g) Provide slides or notes to accompany video lectures, and h) Provide students the ability to vary the speed of the video lectures. Representative comments from the participants include the following:

"What I liked about the course is that most of the lecture videos are relatively short (usually under 15 minutes)." (Student G, Python MOOC)

"The course was taught by a team of experts from many different disciplines so we got a really well rounded look at the subject." (Student R, Epidemics MOOC)

"The video lectures were much easier to watch (due to the short length) than other courses." (Student A, Epidemics MOOC).

"The subtitles have allowed me to follow without any problems." (Student C, Epidemics MOOC)

"The professors use simple language that is easy to comprehend for people even without a background in the area" (Student L, Epidemics MOOC)

"The outside references are provided for those who wish for more information and to go further in the subject." (Student C, Epidemics MOOC)

"I would prefer an alternate written narrative as a supplement or complement to the video as reading would be quicker to get through than watching." (Student Q, Epidemics MOOC)

"The instructors clown around a little in the lecture videos, which at first I found mildly amusing but contrived. However, over time I realized that it made me, the anonymous online viewer, feel like I was getting to know the professors personally, as if I had been sitting in a small university class for the semester. This is a pretty neat trick." (Student A, Python MOOC)

\section{TOWARdS A Model of ENGAGING ONLINE STUdENTS}

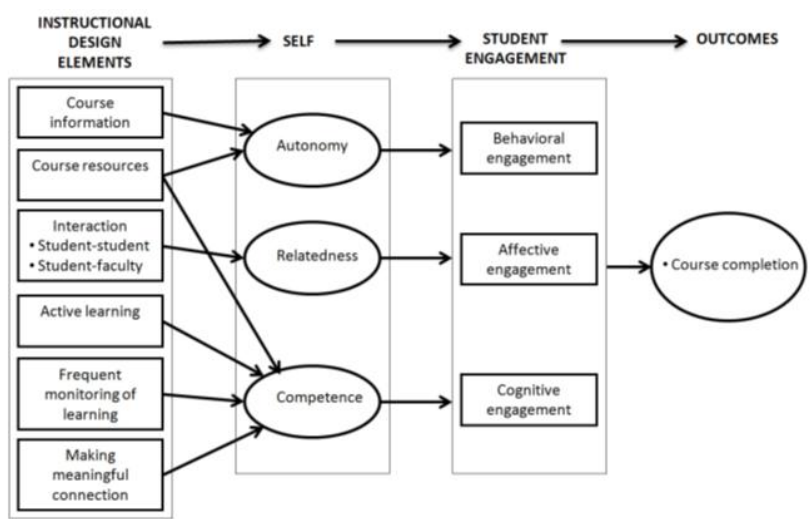

Fig. 3. A model of engaging online students organized around SDT and instructional design elements.

In this section, I outline a rudimentary model of engaging students in online learning courses based on my synthesis of both the various guidelines from the four professional councils, and the results from the participants' comments (see Fig. 3).

TABLE III: GUIDELINES FOR ENGAGING ONLINE STUDENTS

\section{Course information}

a. Provide clear objective of the course

b. State the course duration (e.g., total number of weeks)

c. State the estimated workload (e.g., expected number of hours per week for learning the material)

d. Specify the language in which the course is taught

e. Provide a course syllabus

f. State any recommended pre-requisite or background

g. Provide the course requirement (e.g., type of assessment, criteria for earning a certificate, deadlines)

\section{Fostering active learning}

a. Use of active learning strategies (e.g., mini-projects, online games) so that students could apply some of the principles taught in the lessons

b. Use of self-assessment activity as part of a student's required assignment.

\section{Monitoring of learning}

a. Use of auto-graded weekly quizzes that test the concepts taught in a particular week

b. Use of practice exercises related to each week's lesson. Each exercise contains a problem that students need to solve. Each problem contains two links - one for a template that students could use as a starting point, and the other the instructors' solution to the problem.

IV. Making meaningful connection

a. Make meaningful connection (e.g., real illustrative examples, case studies)

b. Use of assignments that require students to create popular games such as Pong, Blackjack, Asteroids help students make direct connections to the key concepts taught.

\section{Student-student interaction}

a. Use of an asynchronous discussion forum for students to interact. The forum should have a feature to easily track and manage the discussion threads and posts

VI. Student-faculty interaction

a. Responsive to students' questions (e.g., answer forum questions such as the "Ask-us-anything feature")

b. Use of a dedicated course email (e.g., Code Clinic) to seek instructor help. Students could email a link of their work to the Code Clinic and one of the staff would look at the students' code and help debug the specific problem.

VII. Course resources

a. Use of 'bite-size' videos (mostly about 5-6 minutes long for Epidemics MOOC, and between 5-17 minutes for Python MOOC) with relevant pictures and animations to illustrate concepts

b. Present information in simple-to-understand language

c. Use of multiple lecturer model to add various perspectives to the course and keep students interested. Helpful to inject some humor into the presentations.

d. Relevant, interesting, accurate, and up-to-date information

e. Use of captions on videos

f. Downloadable video lectures to avoid potential online stall or crash

g. Provide slides or notes to accompany video lectures

h. Provide students the ability to vary the speed of the video lectures

This rudimentary model of engaging students in online learning courses is based on six instructional design elements: course information, course resources, interaction, active learning, frequent monitoring of learning, and making meaningful connections.

The provision of clear course information and resources would give students a clear idea of what they are actually supposed to do in the course. Further, the use of online video lectures gives students the flexibility to view the content at their own pace and time. All these elements cater to a student's need for autonomy. Interactions between students and faculty, on the other hand, would foster the sense of 
relatedness which in turn affects students' affective engagement. Frequent and meaningful interactions would increase students' positive feelings toward a course and help them stay engaged longer. Finally, the use of relevant course resources, active learning strategies, frequent monitoring of learning, and meaningful connections to real world practice helps foster a students' sense of competence in mastering the subject being studied. More detail guidelines pertaining to each of the instructional design elements are presented in Table III.

\section{CONCLUSION}

The use of online learning is expected to become more widespread in many institutes of higher learning. Although many instructors may desire to use online learning in their courses, engaging students in an online course is not easy. In this paper I analyzed the documents from several online learning professional councils. I have also examined how instructors of two most highly-rated MOOCs promoted student engagement in their online courses. The findings of this study point to the important role that proper instructional design elements can play in engaging online students. One limitation of the current study is that the participants were not randomly sampled. This study examined the comments of participants who posted their reflections voluntarily. Another limitation is that this study did not examine students' actual learning outcome such as grades earned in a MOOC. Future studies can perhaps examined the viewpoints of other silent participants and investigate what factors may predict student learning outcomes.

\section{REFERENCES}

[1] B. Means, Y. Toyama, R. Murphy, M. Bakia, and K. Jones, Evaluation of Evidence-Based Practices in Online Learning: A Meta-Analysis and Review of Online Learning Studies, U.S. Department of Education, Office of Planning, Evaluation, and Policy Development: Washington, D.C, 2010

[2] S. McMinn. (December 2014). MOOCs being embraced by top U.S. universities. USA Today. [Online]. Available: http://www.usatoday.com/story/news/nation/2013/07/11/moocs-top-c olleges-and-universities/2509883/

[3] J. Reeve, "A self-determination theory perspective on student engagement," in Handbook of Research on Student Engagement, S. L. Christenson, A. L. Reschly, and C. Wylie, Eds., New York: Springer, 2012, ch. 7, pp. 149-172.

[4] J. J. Appleton, S. L. Christenson, and M. J. Furlong, "Student engagement with school: Critical conceptual and methodological issues of the construct," Psychology in the Schools, vol. 45, pp. 369-386, 2008.
[5] J. A. Fredricks, P. C. Blumenfled, and A. H. Paris, "School engagement: potential of the concept, state of the evidence," Review of Educational Research, vol. 74, pp. 59-109, 2004.

[6] S. Helme and D. J. Clarke, "We really put our minds to it: Cognitive engagement in the mathematics classroom, Teaching Mathematics in New Times," Brisbane, Qld: Mathematics Education Research Group of Australasia, 1998, pp. 250-257.

[7] E. A. Skinner, T. A. Kindermann, J. P. Connell, and J. G. Wellborn, "Engagement as an organizational construct in the dynamics of motivational development," in Handbook of motivation at school, $\mathrm{K}$. Wentzel and A. Wigfield, Eds., Mahwah, NJ: Erlbaum, 2009, pp. 223-245.

[8] E. L. Deci and R. M. Ryan, Intrinsic motivation and self-determination in human behavior, New York: Plenum Press, 1985.

[9] E. L. Deci and R. M. Ryan, "The 'what' and 'why' of goal pursuits: Human needs and the self-determination of behavior," Psychological Inquiry, vol. 11, pp. 227-268, 2000.

[10] P. L. Hardre and J. Reeve, "A motivational model of students' intentions to persist in, versus drop out of high school," Journal of Educational Psychology, vol. 95, pp. 347-356, 2003.

[11] N. Otis, F. M. E. Grouzet, and L. G. Pelletier, "Latent motivational change in an academic setting: A 3-year longitudinal study," Journal of Educational Psychology, vol. 97, pp. 170-183, 2005.

[12] E. L. Deci and R. M. Ryan, "A motivational approach to self: Integration in personality," in Nebraska symposium on motivation: Perspectives on motivation, R. Dienstbier, Ed., Lincoln, NE University of Nebraska Press, vol. 38, 1991, pp. 237-288.

[13] A. J. Elliot and C. S. Dweck, Eds., Handbook of competence and motivation, New York: Guilford, 2005.

[14] Benchmarks for Technology Supported Teaching and Learning, Australasian Council on open, distance and e-learning, 2008.

[15] Interregional Guidelines for the Evaluation of Distance Education Programs (Online Learning), Council of Regional Accrediting Commissions, 2011.

[16] Open and Distance Learning Quality Council Standards, Open \& Distance Learning Quality Council, 2012.

[17] Guidelines for the Implementation of Effective E-learning Courses based on Collaboration, European Commission, 2008.

[18] C. C. Bonwell and J. A. Eison, Active learning: Creating excitement in the classroom, Washington, DC: ASHE-ERIC Higher Education Report no. 1, 1991

[19] J. Warren, S. Rixner, J. Greiner, and S. Wong, "Facilitating human interaction in an online programming course," presented at SIGCSE'14, March 5-8, 2014, Atlanta, GA, ACM, 2014.

[20] K. F. Hew and W. S. Cheung, Student Participation in Online Discussions: Challenges, Solutions, and Future Research, Springer, NY, 2012.

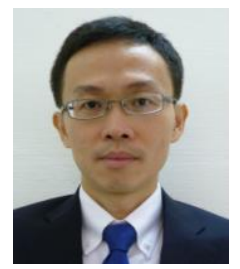

Khe Foon Hew is an associate professor of information and technology studies at the Faculty of Education, The University of Hong Kong. His research primarily focuses on computer-supported interaction, and technology-mediated learning. He has won several awards including the 2006 Educational Technology Research \& Development Young Scholar Award, the 2011 IGI Global 4th Annual Excellence in Research Journal Award, a Best Paper Award at the 2012 International Conference on ICT in Teaching and Learning, and a Best Presentation Award at the 2013 International Conference on Knowledge and Education Technology. 